\title{
PENERAPAN MODEL ACTIVE LEARNING START WITH A QUESTION UNTUK MENINGKATKAN AKTIVITAS BELAJAR MATEMATIKA SISWA KELAS VII DI SMP NEGERI 6 KOTA BENGKULU
}

\author{
${ }^{1}$ Nopriza Rahmawati, ${ }^{2}$ Rusdi, ${ }^{3}$ Hanifah \\ ${ }^{1}$ Program Studi Pendidikan Matematika, FKIP Universitas Bengkulu \\ email : ${ }^{1}$ noprizarahma@gmail.com, ${ }^{2}$ rusdipendmat12@gmail.com dan ${ }^{3}$ hanifah@unib.ac.id
}

\begin{abstract}
Abstrak
Penelitian ini bertujuan untuk mengetahui cara menerapkan Model Active Learning Start With A Question sehingga dapat meningkatkan hasil belajar siswa pada pokok bahasan segiempat dan segitiga. Jenis penelitian ini adalah Penelitian Tindakan Kelas (PTK). Subjek Penelitian ini adalah 22 siswa kelas VIIB SMP Negeri 6 Kota Bengkulu semester genap tahun ajaran 2017/2018. Instrumen yang digunakan adalah adalah lembar observasi aktivitas siswa. Hasil penelitian menunjukkan terjadi peningkatan aktivitas belajar siswa yang dilakukan dengan cara membentuk kelompok diskusi yang heterogen, menggunakan bahan ajar berupa handout, membimbing untuk mengambil andil tugas kegiatan kelompok, dan memberikan motivasi dan apresiasi berupa nilai plus dan pujian. Peningkatan aktivitas belajar dapat dilihat dari rata-rata skor pada lembar observasi aktivitas belajar siswa siklus I sampai siklus III secara berturut-turut: 14 (kriteria kurang); 20,375 (kriteria cukup); 26,5 (kriteria baik).
\end{abstract}

Kata kunci: Aktivitas Belajar, Model Active Learning Start With A Question

\begin{abstract}
This study aims to find out how to apply Active Learning Start With A Question Models so as to improve learning outcomes of mathematics on the topics of rectangle and triangle. This type of research is Classroom Action Research (CAR). The subject of this research is 22 students of class VII B SMP Negeri 6 Bengkulu City even semester of 2017/2018 academic year. The instrument used is activity observation sheets. The results showed that there was an improvement in the student's learning activities by forming heterogeneous discussion groups, using handout as assistance, guiding them to take on the task of group activities, and providing motivation and appreciation in the form of plus values and praise. The improvement of learning activity can be seen from the average score on the observation sheets of student learning activities from cycle I to cycle III respectively: 14 (less criteria); 20,375 (sufficient criteria); 26,5 (good criteria).
\end{abstract}

Keywords: Learning Activity, Active Learning Start With A Question Models

\section{PENDAHULUAN}

Matematika merupakan mata pelajaran yang sangat dibutuhkan dalam kehidupan sehari-hari. Banyak permasalahan yang dapat diselesaikan dengan teori-teori matematika. Matematika sebagai salah satu ilmu dasar memiliki peranan penting dalam mencerdaskan siswa karena dapat menumbuhkan kemampuan penalaran yang sangat dibutuhkan dalam perkembangan ilmu dan teknologi. Pelajaran matematika juga memiliki sifat yang abstrak, pemahaman

Nopriza, Rusdi, Hanifah

Penerapan Model Active Learning Start With a Question Untuk Meningkatkan Aktivitas Belajar Matematika Siswa Kelas VII di SMP Negeri 6 Kota Bengkulu 
konsep yang benar sangat penting karena untuk memahami konsep matematika yang baru diperlukan prasyarat pemahaman terhadap konsep tersebut. Oleh sebab itu matematika menjadi salah satu mata pelajaran yang wajib dipelajari oleh siswa di setiap jenjang pendidikan.

Pembelajaran matematika di sekolah bertujuan untuk mempersiapkan siswa agar sanggup menghadapi perubahan keadaan di dalam kehidupan dan di dunia yang selalu berkembang melalui latihan bertindak atas dasar pemikiran secara logis, rasional, kritis, cermat, jujur, efisien dan efektif. Pembelajaran Matematika di sekolah selama ini masih didominasi oleh pembelajaran konvensional dimana siswa diposisikan sebagai objek pembelajaran, siswa dianggap tidak tahu atau belum mengerti apa-apa, sementara guru memposisikan diri sebagai seorang yang mempunyai pengetahuan. Sehingga guru terkesan menggurui dan memiliki otoritas tertinggi dalam proses pembelajaran.

Pembelajaran matematika pada umumnya masih menggunakan metode konvensional. Guru juga cenderung mengajarkan sesuatu sebagaimana sesuatu itu dulunya diajarkan padanya, dan model pembelajaran ceramah dan menulis merupakan model yang umum (Silberman, 2016: 11). Hal ini mengakibatkan siswa pasif karena sebagian besar proses pembelajaran didominasi oleh guru, siswa hanya mendengarkan dan mencatat materi pokok dari penyampaian guru sehingga keaktifan siswa dalam mengikuti proses pembelajaran hampir tidak ada. Siswa dikatakan belajar aktif jika ada mobilitas, misalnya nampak dari interaksi yang terjadi antara guru dengan siswa dan antara siswa itu sendiri. Komunikasi yang terjadi tidak hanya satu arah dari guru ke siswa tetapi ke banyak arah.

Berdasarkan observasi peneliti selama magang 3 pada tanggal 12 Agustus - 12 November 2017 di SMP Negeri 6 Kota Bengkulu, banyak siswa yang kurang semangat ketika belajar matematika. Hal ini tentunya sangat berpengaruh terhadap hasil belajar matematika siswa. Selain itu, proses belajar mengajar yang terjadi yaitu belum adanya interaksi antara siswa dengan guru ataupun siswa dengan siswa. Sehingga, siswa cenderung bosan saat belajar karena aktivitas yang mereka lakukan hanya mendengarkan dan mencatat penjelasan dari guru.

Peneliti juga melakukan wawancara dengan salah satu guru matematika kelas VII SMP Negeri 6 Kota Bengkulu pada tanggal 31 Januari 2018. Ternyata, sama seperti pengalaman peneliti sebelumnya, yaitu diperoleh informasi bahwa hasil belajar siswa masih rendah dan terdapat banyak siswa yang memperoleh hasil belajar dibawah Kriteria Ketuntasan Minimal (KKM) yang ditetapkan sekolah untuk mata pelajaran matematika di kelas VII yaitu 70. Hal itu dikarenakan siswa kurang bersemangat ketika belajar matematika. Dan berdasarkan data yang didapatkan, setiap kelas memiliki rata-rata nilai yang rendah. Salah satunya yaitu kelas VIIB dengan nilai rata-rata siswanya pada ulangan semester ganjil tahun ajaran 2017/2018 yaitu 44,8. Dalam proses pembelajaran di kelas, keaktifan siswa masih rendah. Hal ini dapat dilihat dari masih rendahnya keaktifan bertanya, mengemukakan ide dan keaktifan mengerjakan latihan soal-soal di depan kelas. Siswa cenderung tidak berani menanyakan materi yang belum paham kepada guru, walaupun guru telah memberikan kesempatan bertanya. Padahal, keaktifan siswa di kelas merupakan hal yang penting untuk meningkatkan hasil belajar siswa.

Menghadapi persoalan tersebut, berbagai upaya bisa dilakukan guru agar dapat mengambil suatu tindakan guna menyiasati apa yang terjadi dalam proses pembelajaran di kelas. Salah satunya dengan menggunakan model pembelajaran yang tepat. Model pembelajaran adalah pola yang digunakan sebagai pedoman dalam merencanakan pembelajaran di kelas maupun teritorial (Suprijono,2014: 46). Model pembelajaran yang tepat dalam proses pembelajaran termasuk faktor yang turut menentukan keberhasilan 
pembelajaran. Penerapan model pembelajaran dilakukan untuk memudahkan siswa memahami pelajaran yang menyenangkan sehingga aktivitas siswa lebih nampak. Penggunaan model dalam pembelajaran akan membantu kelancaran, efektifitas dan efisiensi pencapaian tujuan. Adapun model-model pembelajaran yang dapat diterapkan dalam pembelajaran yaitu model pembelajaran kooperatif (cooperative learning), pembelajaran inkuiri (inquiry learning), pembelajaran kolaboratif (collaborative learning), pembelajaran efektif (effective learning), pembelajaran konstektual (contextual learning), pembelajaran afektif (affective learning), pembelajaran aktif (active learning) dan model pembelajaran lainnya. Sehingga, untuk mencapai tujuan agar siswa aktif dalam pembelajaran dan meningkatnya hasil belajar, peneliti menggunakan model pembelajaran aktif (active learning) yaitu pembelajaran yang menuntut siswa agar aktif ketika pembelajaran di kelas. Model pembelajaran aktif mempunyai berbagai tipe, salah satunya adalah Learning Starts With A Question (LSQ).

Learning Starts With A Question (LSQ) merupakan salah satu tipe dari model pembelajaran aktif yang dapat diterapkan dalam pembelajaran matematika. Tipe ini memancing siswa untuk mengajukan banyak pertanyaan kepada guru. Siswa diminta untuk menyelidiki atau mempelajari materi pelajaran, tanpa penjelasan dari guru terlebih dahulu. Dengan adanya pertanyaan-pertanyaan siswa, guru dapat mengetahui sejauh mana pemahaman dan penguasaan siswa terhadap materi yang dipelajari (Wartahati,Edriati dan Handayani, 2015: 2-3)

Model active learning start with a question yang diterapkan dalam proses pembelajaran diharapkan dapat menghilangkan rasa bosan siswa saat belajar. Siswa dapat memahami materi pembelajaran serta bisa saling bertukar pikiran dengan teman-temannya. Hal ini dapat membuat kelas lebih aktif dan menyenangkan, sehingga siswa akan lebih semangat belajar.
Langkah-langkah model learning start with

a question adalah sebagai berikut

(Muhammadi,2011: 169).

1. Pilih bahan bacaan yang sesuai dengan materi pembelajaran.

2. Peserta didik mempelajari bahan bacaan tersebut secara sendiri atau bersama temannya.

3. Peserta didik ditugaskan untuk memberi tanda pada bagian yang tidak dipahami peserta didik.

4. Minta peserta didik memberi tanda sebanyak mungkin.

5. Gabungkan semua poin-poin yang tidak dipahami peserta didik tersebut.

6. Kemudian minta peserta didik membahas poin-poin tersebut.

7. Di dalam pasangan atau kelompok kecil minta peserta didik menuliskan pertanyaan tentang materi yang telah mereka pelajari.

8. Kumpulkan semua pertanyaan tersebut.

9. Sampaikan materi pembelajaran dengan menjawab semua pertanyaan tersebut.

Selanjutnya, langkah-langkah learning start with a question menurut Silberman (2012: 157-158) adalah sebagai berikut.

1. Bagikan kepada siswa bahan ajar yang Anda pilih sendiri. (Anda dapat menggunakan satu halaman dalam sebuah buku teks, sebagai ganti buku pegangan). Inti dari pilihan materi anda adalah kebutuhan untuk menstimulir pertanyaaan di pihak pembaca. Sebuah buku pegangan yang menyediakan informasi luas namun tidak memiliki rincian penjelas adalah yang ideal.

2. Perintahkan kepada siswa untuk mempelajari buku pegangan dengan pasangannya. Perintahkan agar masingmasing pasangan sebisa mungkin berupaya memahami buku pegangan dan mengenali apa saja yang tidak mereka pahami dengan menandai dokumen dengan pertanyaan di dekat informasi yang tidak mereka pahami. Anjurkan siswa untuk menyisipkan sebanyak mungkin tanda tanya sesuai yang mereka kehendaki. Jika waktunya memungkinkan, bentuklah pasangan- 
pasangan tersebut menjadi kuartet (kelompok empat siswa) dan beri waktu bagi tiap pasangan untuk saling membantu.

3. Perintahkan siswa untuk kembali ke posisi semula dan jawablah pertanyaan-pertanyaan siswa, anda mengajar melalui jawaban anda atas pertanyaan siswa secara keseluruhan, dan baru kemudian mengajarkan mata pelajaran hari ini, dengan melakukan upaya khusus untuk menjawab pertanyaan yang diajukan oleh siswa.

Saat ini sekolah sudah menggunakan kurikulum 2013 yang menerakan pendekatan saintifik. Pembelajaran saintifik memandang siswa sebagai subyek belajar bukan lagi sebagai obyek belajar sehingga siswa memegang peran utama dalam pembelajaran (Suseno, 2016). Pendekatan saintifik adalah proses pembelajaran yang dirancang sedemikian rupa agar peserta didik secara aktif mengkonstruk konsep, hukum atau prinsip melalui komponen mengamati (untuk mengidentifikasi atau menemukan masalah), merumuskan masalah, mengajukan atau merumuskan hipotesis, mengumpulkan data dengan berbagai teknik, menganalisis data, menarik kesimpulan dan mengkomunikasikan konsep, hukum atau prinsip yang "ditemukan" (Hosnan, 2014:34).

Berdasarkan langkah-langkah menurut beberapa ahli mengenai tahapan model active learning start with a question. Maka tahapan yang akan dilaksanakan mengacu pada langkah Muhammadi dengan memodifikasi pada bagian tertentu diimbangi dengan pendekatan saintifik, adapun tahapannya yaitu:

1. Tahap membaca dan memahami materi (Mengamati)

2. Tahap menandai pada bagian yang tidak dipahami

3. Tahap membuat pertanyaan (Menanya)

4. Tahap menjawab pertanyaan (Mengkomunikasikan)

5. Tahap mengerjakan soal-soal latihan

Tahap pertama, membaca dan memahami materi dimulai dengan guru membagikan bahan bacaan sesuai dengan materi pembelajaran.
Bahan ajar yang dibagikan yaitu berupa handout. Handout dibuat dan dirancang sendiri oleh guru sebagai peneliti. Tahap kedua, menandai pada bagian yang tidak dipahami, peserta didik diminta untuk membaca dan mempelajari materi yang ada pada handout yang telah diberikan. Dianjurkan untuk memberikan tanda sebanyak mungkin dan identifikasi apa yang tidak mereka mengerti. Tahap ketiga, membuat pertanyaan, pada tahap ini guru membagi peserta didik dalam kelompok, kemudian guru meminta siswa untuk mencatat pertanyaan-pertanyaan yang sudah mereka tandai, kemudian saling berdiskusi mengenai jawaban dari pertanyaanpertanyaan yang sudah mereka baca dan tandai sebelumnya. Tahap keempat yaitu menjawab pertanyaan, guru meminta satu dari perwakilan kelompok untuk membacakan hasil diskusi kelompok. Kemudian, guru meminta kelompok lain untuk memperhatikan dan menanggapi penjelasan dari kelompok yang membacakan hasil diskusinya. Jika terdapat kekeliruan ataupun kendala mengenai jawaban ketika peserta didik berdiskusi, guru menyampaikan materi pelajaran tersebut dengan membantu menjawab dan menjelaskan hal-hal yang peserta didik belum pahami. Tahap kelima adalah mengerjakan soal-soal latihan, guru membagikan soal-soal latihan pada tiap kelompok. Kemudian peserta didik diminta untuk menjawab soal-soal latihan tersebut. Setelah semua kelompok mengerjakan soalsoal latihan, guru meminta salah satu peserta didik untuk menyimpulkan materi yang dipelajari.

\section{Kelebihan dan Kekurangan Learning Start With A Question}

Adapun Kelebihan dan Kekurangan model learning start with a question antara lain (Susatyo, Rahayu, dan Yuliawati, 2009: 407):

1. Kelebihan dari model Learning Start With A Question adalah:
a. Peserta didik terpancing untuk berfikir dan bertanya.
b. Pembelajaran menjadi lebih menarik dan interaktif.


c. Kualitas pembelajaran dapat ditingkatan.

d. Meningkatkan sikap positif peserta didik terhadap materi pembelajaran.

Kelemahan dari model Learning Start With A Question adalah:

a. Pelaksanaan pembelajaran harus dilakukan dengan kreatif dan vokal yang mampu mencakup kelas.

b. Guru harus mampu menjadi moderator dan fasilitator yang baik.

Bedasarkan latar belakang yang telah diuraikan di atas, maka penelitian yang akan diajukan berjudul "penerapan model active learning start with a question untuk meningkatkan hasil belajar matematika siswa kelas VII di SMP Negeri 6 Kota Bengkulu" dan diharapkan setelah dilakukan penelitian maka hasil belajar siswa dapat meningkat dari sebelumnya.

\section{METODE}

Jenis penelitian yang dilakukan adalah penelitian tindakan kelas (PTK). Kunandar (2013: 44-45) berpendapat bahwa PTK merupakan suatu penelitian tindakan yang dilakukan oleh guru yang sekaligus sebagai peneliti di kelasnya atau bersama-sama dengan orang lain (kolaborasi) dengan jalan merancang, melaksanakan dan merefleksikan tindakan secara kolaboratif dan partisipatif yang bertujuan untuk memperbaiki atau meningkatkan mutu proses pembelajaran di kelasnya melalui suatu tindakan tertentu dalam suatu siklus.

Penelitian Tindakan Kelas (PTK) diawali dari adanya masalah yang dirasakan oleh guru dalam pembelajaran di kelas. Masalah tersebut kemudian dianalisis dan direfleksi untuk diketahui faktor-faktor penyebabnya. Setelah jelas faktor penyebabnya, selanjutnya masalah tersebut dirumuskan secara jelas, baik dengan kalimat tanya maupun dengan kalimat pernyataan dan kemudian dicari strategi atau metode untuk memecahkan masalah tersebut.

Tahapan-tahapan dalam PTK menurut Arikunto,Suhardjono dan Supardi (2014: 16) yaitu (1) perencanaan, (2) pelaksanaan, (3) pengamatan, dan (4) refleksi.

Materi yang diajarkan dalam penelitian ini adalah segiempat dan segitiga yang merupakan salah satu pokok bahasan dalam silabus matematika kelas VII Sekolah Menengah Pertama/Madrasah Tsanawiyah (SMP/MTs) kurikulum 2013.

Penggunaan bahan ajar juga dapat menciptakan pembelajaran yang lebih bermakna. Bahan ajar membantu siswa sehingga mereka tidak lagi terpaku pada penjelasan guru. Siswa dengan bebas menggali pengetahuan dan informasi sendiri serta dapat mengembangkan apa yang telah dimilikinya tersebut. Dengan menggunakan bahan ajar selama proses pembelajaran, maka akan tercipta susasana yang atraktif dan komunikatif serta mengurangi dominasi guru. Pada penelitian ini bahan ajar yang digunakan yaitu handout. Handout dimaksudkan untuk memperlancar dan memberikan bantuan informasi materi pembelajaran sebagai pegangan bagi siswa.

Selanjutnya, subjek dalam penelitian ini yaitu peserta didik Kelas VII B SMP Negeri 6 Kota Bengkulu yang berjumlah 22 peserta didik yang terdiri dari 7 orang laki- laki dan 15 orang perempuan. Berdasarkan data nilai matematika yang diperoleh di kelas VII B pada ulangan semester ganjil tahun ajaran 2017/2018 yang masih tergolong rendah dengan rata-rata 44,8 . Sehingga, masih banyak terdapat peserta didik yang nilainya belum mencapai Kriteria Ketuntasan Minimal (KKM) yang telah ditentukan, yaitu 70.

Prosedur penelitian yang dilaksanakan adalah Penelitian Tindakan Kelas terdiri dari tiga siklus. Setiap siklus terdiri dari empat tahapan yaitu :(1)Menyusun rancangan tindakan (Planning) dalam tahap menyusun rancangan ini peneliti menentukan titik atau fokus peristiwa yang perlu mendapatkan perhatian khusus untuk diamati, kemudian membuat sebuah instrumen pengamatan untuk membantu peneliti merekam fakta yang terjadi selama tindakan berlangsung. Perencanaan 
disusun berdasarkan masalah dan hipotesis tindakan yang diuji secara empirik sehingga perubahan yang diharapkan dapat mengidentifikasi aspek dan hasil dari proses belajar mengajar. (2) Pelaksanaan Tindakan (Acting) penelitian tindakan adalah pelaksanaan yang merupakan implementasi atau penerapan isi rancangan, yaitu mengenakan tindakan kelas. Penelitian tindakan didasarkan atas pertimbangan teoritis dan empiris agar hasil yang diperoleh berupa peningkatan proses belajar mengajar.(3) Pengamatan (Observing) pengamatan yaitu kegiatan yang dilakukan oleh pengamat. Pengamatan perlu direncanakan dan juga didasarkan dengan keterbukaan pandangan dan pikiran serta bersifat responsif.(4) Refleksi (Reflecting) refleksi merupakan kegiatan untuk mengemukakan kembali apa yang sudah dilakukan. Kegiatan refleksi ini sangat tepat dilakukan ketika guru pelaksana sudah selesai melakukan tindakan, kemudian berhadapan dengan peneliti untuk mendiskusikan implementasi rancangan tindakan.

Instrumen yang digunakan dalam penelitian ini adalah aktivitas peserta didik.Aktivitas belajar merupakan perbuatan atau tindakan yang menghasilkan sebuah perubahan tingkah laku seseorang. Oleh karena itu, aktivitas belajar adalah hal penting dalam proses belajar mengajar. Aktivitas belajar menurut Kunandar (2013: 277) adalah keterlibatan peserta didik dalam bentuk sikap, pikiran, perhatian, dan aktivitas dalam kegiatan pembelajaran untuk menunjang keberhasilan dan memperoleh manfaat dari proses belajar mengajar tersebut.

Hal tersebut sejalan dengan pendapat Supriyadi (2015: 174) yang menyatakan bahwa mengaktifkan belajar siswa adalah dengan memberikan berbagai pengalaman belajar bermakna yang bermanfaat bagi kehidupan siswa dengan memberikan rangsangan tugas, tantangan, memecahkan masalah, atau mengembangkan pembiasaan agar dalam dirinya tumbuh kesadaran bahwa belajar menjadi kebutuhan hidupnya dan oleh karena itu perlu dilakukan sepanjang hayat.
Berdasarkan beberapa pendapat diatas, dapat disimpulkan bahwa aktivitas belajar siswa merupakan kegiatan pembelajaran yang didalamnya siswa mempunyai keterlibatan langsung untuk memperoleh manfaat-manfaat dan perubahan perilaku baik dalam aspek kognitif, afektif dan psikomotor.

Aktivitas belajar menurut Paul B. Diedrich menyatakan bahwa aktivitas belajar dapat digolongkan sebagai berikut (Sardiman,2011: 101):

1. Visual activities, misalnya membaca, memperhatikan gambar demonstrasi, percobaan, dan mengamati pekerjaan orang lain.

2. Oral activities, misalnya menyatakan, merumuskan, bertanya, memberi saran, mengemukakan pendapat, mengadakan wawancara, diskusi dan interupsi.

3. Listening activities, misalnya mendengarkan penyajian bahan, percakapan, diskusi, music, dan pidato.

4. Writing activities, misalnya menulis cerita, karangan, laporan, mengisi angket, dan menyalin.

5. Drawing activities, misalnya menggambar, membuat grafik, peta, dan diagram.

6. Motor activities, misalnya melakukan percobaan, membuat konstruksi.

7. Mental activities, misalnya menanggapi, mengingat, memecahkan masalah, menganalisis, melihat hubungan-hubungan, dan membuat keputusan.

8. Emosional activities, misalnya minat, merasa bosan, gembira, bersemangat, berani, tenang, gugup.

Pada penelitian ini, aktivitas belajar yang lebih difokuskan adalah visual activities, oral activities, listening activities, writing activities, dan mental activities, yang disesuaikan dengan langkah-langkah model learning start with a question.

Lembar observasi pengamatan aktivitas belajar yang didapat selama proses pembelajaran dengan menerapkan model learning start with a question dengan 
pendekatan saintifik, diolah dengan ketentuan sebagai berikut:

Tabel 1 Kriteria Penilaian untuk Lembar Observasi Aktivitas Peserta Didik

\begin{tabular}{|c|c|c|}
\hline $\begin{array}{c}\text { Kriteria } \\
\text { Penilaian }\end{array}$ & Notasi & Skor \\
\hline Kurang & $\mathrm{K}$ & 1 \\
\hline Cukup & $\mathrm{C}$ & 2 \\
\hline Baik & $\mathrm{B}$ & 3 \\
\hline \multicolumn{3}{|c|}{ (Sudjana, 2016: 77-78) } \\
\hline
\end{tabular}

Kisaran nilai aktivitas belajar peserta didik:

Kisaran nilai untuk tiap kriteria

$$
=\frac{\text { Skor Tertinggi }- \text { Skor Terendah }+1}{\text { Jumlah Kriteria }}
$$

(Sudijono, 2008:330-331)

Keterangan :

Skor tertinggi $=$ jumlah butir observasi $\mathrm{x}$ skor tertinggi tiap butir observasi.

Skor terendah $=$ jumlah butir observasi $\mathrm{x}$ skor terendah tiap butir observasi.

Observasi aktivitas peserta didik dilakukan oleh dua orang pengamat, maka nilai rata-rata skor dapat diolah dengan menggunakan rumus berikut ini:

$$
\text { nilai } \operatorname{skor}(x)=\frac{P 1+P 2}{2}
$$

(Sudjana, 2016:109)

Keterangan :

$\bar{x}=$ nilai rata-rata skor aktivitas siswa

$P_{1}=$ jumlah skor aktivitas yang diamati oleh pengamat 1

$P_{2}=$ jumlah skor aktivitas yang diamati oleh pengamat 2

Pada penelitian ini, jumlah butir aktivitas peserta didik adalah 10 , Skor tertinggi $3 \times$ $10=30$ dan skor terendah $1 \times 10=10$.

Diperoleh kisaran nilai tiap kriteria yaitu:

$$
=\frac{\text { Skor Tertinggi }- \text { Skor Terendah }+1}{\text { Jumlah Kriteria }}
$$

$$
\begin{aligned}
& =\frac{(30-10)+1}{3} \\
& =7
\end{aligned}
$$

Jadi, diperoleh kriteria penilaian lembar observasi siswa yaitu 7 .

Sehingga, diperoleh kisaran skor untuk lembar observasi peserta didik adalah sebagai berikut:

Tabel 2 Kisaran Skor Lembar Observasi Aktivitas Peserta Didik

\begin{tabular}{|c|c|}
\hline Kriteria Penilaian & Kisaran Skor \\
\hline Kurang Aktif & $10 \leq x \leq 16$ \\
\hline Cukup Aktif & $16<x \leq 23$ \\
\hline Aktif & $23<x \leq 30$ \\
\hline
\end{tabular}

Keterangan :

$\mathrm{x}=$ Rata-rata skor hasil observasi

\section{HASIL DAN PEMBAHASAN}

Pelaksanaan penelitian ini dilakukan dari akhir bulan Maret hingga bulan Mei 2018 . Kegiatan yang pertama dilakukan adalah pengamatan terhadap sasaran penelitian untuk mendapatkan informasi serta refleksi awal mengenai proses pembelajaran, kemudian dilakukan pelaksanaan penelitian yang dibagi menjadi tiga siklus. Setiap siklus meliputi tahapan perencanaan, pelaksanaan tindakan, observasi dan refleksi yang akan menghasilkan perbaikan. Pada sub-bab ini akan dipaparkan hasil dari pelaksanaan penelitian dimulai dari refleksi awal hingga siklus tiga berakhir.

Pada proses pembelajaran yang terjadi di kelas, aktivitas peserta didik dinilai. Pengamatan kegiatan belajar di kelas menggunakan lembar observasi peserta didik dengan 10 butir pernyataan sebagai berikut:(1)Siswa mendengarkan pengarahan dan penjelasan dari guru.(2)Siswa aktif membaca materi pembelajaran yang ada pada handout yang diberikan. (3) Siswa aktif memberikan tanda pada bagian yang tidak dipahami.(4)Siswa tertib ketika guru mengatur pembentukan kelompok.(5) Siswa aktif melaksanakan diskusi kelompok sesuai petunjuk guru.(6)Siswa memperhatikan guru menyampaikan bagian 
dari materi-materi yang telah didiskusikan siswa.(7)Siswa aktif mengerjakan soal-soal latihan yang diberikan.(8)Siswa percaya diri pada hasil kerja kelompok (9)Tidak melakukan kegiatan lain saat proses belajar mengajar berlangsung. (10) Siswa mampu menyimpulkan hasil pembelajaran tentang materi yang telah dipelajari.

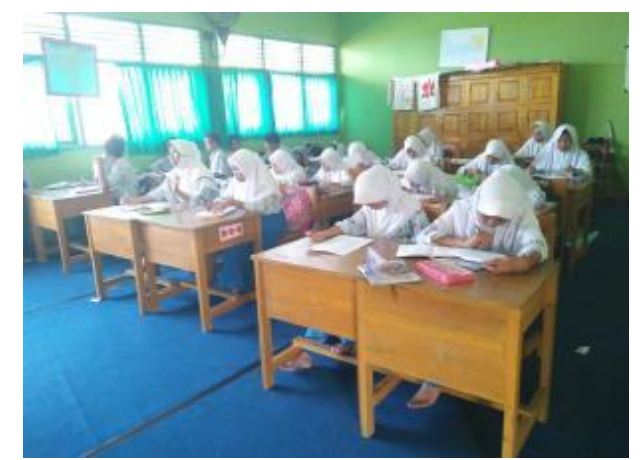

Gambar 1. Aktivitas Peserta Didik Pada Tahap Membaca dan Memahami Materi

Pada gambar 1 menunjukkan bahwa peserta didik membaca dan memahami materi yang ada pada handout yang dibagikan guru. Materi yang dibaca peserta didik berbeda tiap pertemuan.

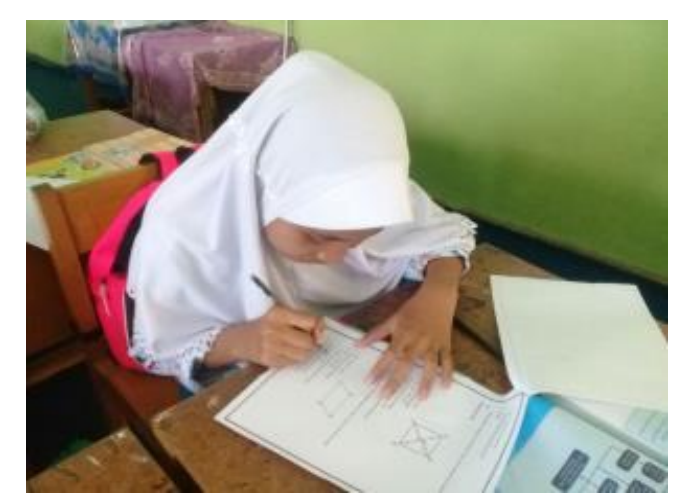

Gambar 2. Aktivitas Peserta Didik Pada Tahap Menandai pada Bagian yang Tidak Dipahami

Peserta didik pada gambar 2 melakukan aktivitas tahap 2, yaitu menandai pada bagian yang tidak dipahami. Guru memerintahkan peserta didik untuk menandai bagian sebanyak mungkin agar ketika diskusi kelompok dan diskusi kelas banyak yang akan dibahas. Sehingga, pengetahuan yang didapatkan juga banyak

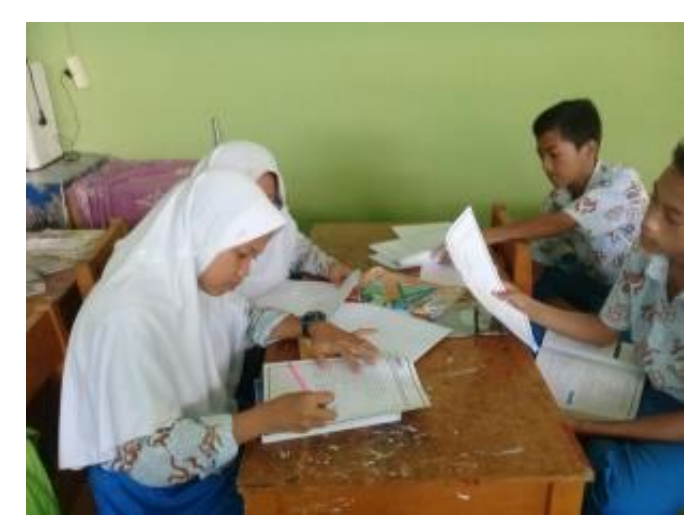

Gambar 3. Aktivitas Peserta Didik Pada Tahap Membuat Pertanyaan

Terlihat pada gambar 3, salah satu kelompok yang sedang berdiskusi dan memberikan pendapat untuk menuliskan pertanyaan. Salah satu anggota ditugaskan untuk menuli pertanyaan, kemudian mereka saling bekerjasama membuat pertanyaan dan jawaban dari pertanyaan yang telah dibuat.

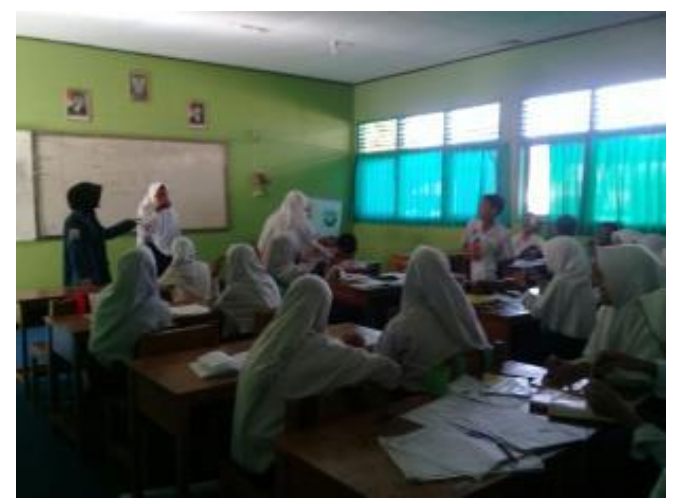

Gambar 4. Aktivitas Peserta Didik Pada Tahap Menjawab Pertanyaan

Pada gambar 4, memperlihatkan seorang peserta didik menjelaskan hasil diskusi kelompoknya dan memberikan penjelasan terhadap peserta didik lainnya. Peserta didik lainnya diminta untuk memperhatikan temannya yang sedang mempresentasikan hasil diskusi, kemudian mereka diminta untuk bertanya dan menanggapi hasil dari diskusi kelompok pennyaji. 


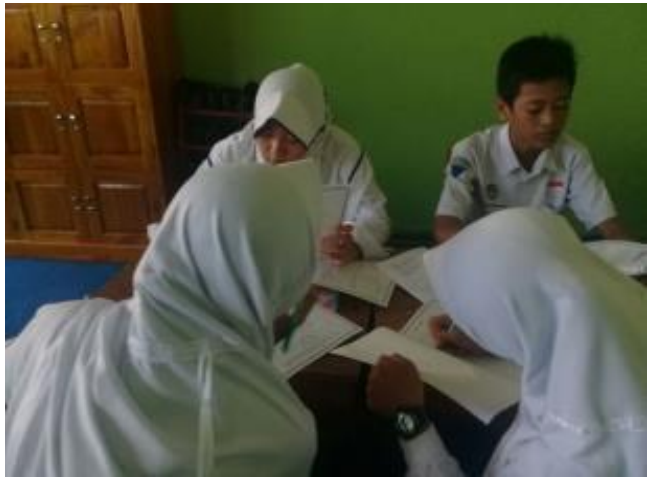

Gambar 5. Aktivitas Peserta Didik Pada Tahap Mengerjakan Soal-soal Latihan

Pada gambar 5, terlihat salah satu kelompok sedang berdiskusi untuk menjawan soal-soal latihan yang diberikan guru. Peserta didik dalam kelompok saling menyampaikan pendapat dan juga bekerjasama.

\section{Pembahasan}

Aktivitas peserta didik dinilai dari lembar aktivitas siswa yang diamati oleh 2 pengamat yaitu teman sejawat. Penerapan model active learning start with a question ini dilaksanakan dalam 3 siklus, yaitu siklus I, siklus II, dan siklus III.

Pengamatan kegiatan belajar di kelas menggunakan lembar observasi peserta didik dengan 10 butir pernyataan.

Tabel 3 Rata-rata Skor Aktivitas Peserta Didik Siklus I, II, dan III

\begin{tabular}{|c|c|c|c|}
\hline Siklus & $\begin{array}{c}\text { Rata-Rata } \\
\text { Skor }\end{array}$ & Kriteria & Keterangan \\
\hline I & 14 & Kurang Aktif & Belum Berhasil \\
\hline II & 20,375 & Cukup Aktif & Belum Berhasil \\
\hline III & 26,5 & Aktif & Berhasil \\
\hline
\end{tabular}

Data pada Tabel 3 di atas menunjukan bahwa aktivitas belajar peserta didik yang diamati oleh dua orang pengamat meningkat setiap siklus. Skor rata-rata pada siklus I yaitu 14 kemudian pada siklus II skor rata-ratanya menjadi 20,375 dan skor rata-rata pada siklus III meningkat lagi menjadi 26,5. Siklus II dan III skor rata-rata aktivitas belajar peserta didik mencapai 20,375 dan 26,5. Hal ini berarti pada siklus III aktivitas belajar peserta didik sudah mencapai kriteria keberhasilan. Aktivitas belajar peserta didik selalu mengalami peningkatan setiap siklusnya. Berdasarkan aktivitas belajar peserta didik pada setiap siklus, perkembangan aktivitas belajar peserta didik mempunyai angka yang beragam, seperti pada gambar 6 sebagai berikut:

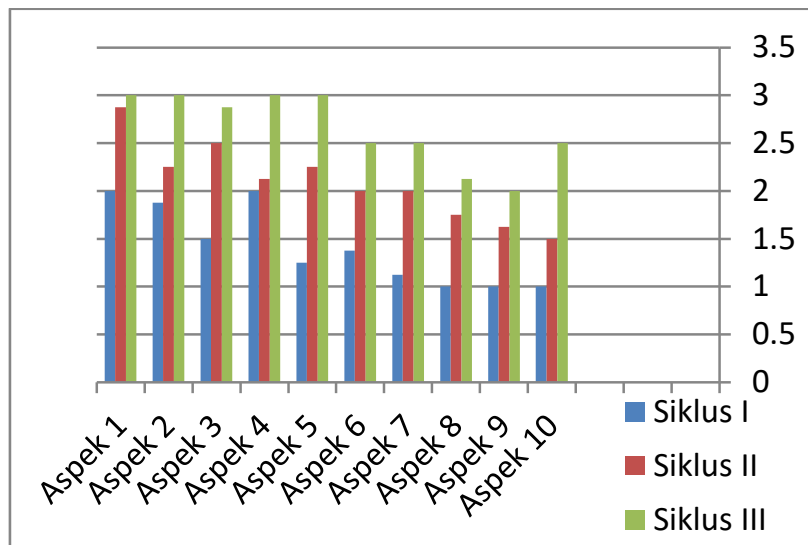

\section{Gambar 6. Perkembangan Aktivitas Peserta Didik per aspek tiap Siklus}

Pada grafik tersebut menunjukkan perkembangan skor rata-rata observasi aktivitas peserta didik setiap pernyataan selalu meningkat atau tetap setiap siklusnya. Peningkatan skor terjadi hampir pada semua pernyataan. Siklus I ke siklus II semua pernyataan mengalami angka yang tetap dan meningkat. Pernyataan 1, 2, 4 dan 5 serta pernyataan lainnya meningkat. Siklus II ke siklus III yang mengalami angka yang tetap yaitu pernyataan 8 dan 9 selain itu mengalami peningkatan.

Analisis hasil belajar secara keseluruhan bahwa peserta didik menunjukkan secara umum aktivitas belajar peserta didik mengalami peningkatan dari siklus I sampai pada siklus III dan sudah mencapai indikator penilaian yang ditetapkan. Sehingga penerapan model active learning start with a question juga dapat meningkatkan aktivitas belajar peserta didik. 


\section{PENUTUP}

\section{Simpulan}

Berdasarkan hasil penelitian yang telah dilakukan, pembelajaran matematika dengan penerapan model active learning start with a question dengan pendekatan saintifik berbantuan handout pada pokok bahasan segiempat dan segitiga yang telah dilaksanakan di kelas VII B SMP Negeri 6 Kota Bengkulu tahun ajaran 2017/2018 dapat disimpulkan bahwa penerapan model active learning start with a question dengan pendekatan saintifik berbantuan handout dapat meningkatkan aktivitas belajar siswa pada pokok bahasan segiempat dan segitiga yang telah dilaksanakan di kelas VII B SMP Negeri 6 Kota Bengkulu dengan cara :

a. Peserta didik dibentuk dalam kelompok belajar yang heterogen berdasarkan kemampuan akademis siswa agar siswa yang pintar dapat saling berbagi pengetahuan dengan siswa yang berkemampuan sedang atau rendah.

b. Peserta didik dilibatkan secara aktif dalam kegiatan pembelajaran model active learning start with a question dari tahap awal hingga akhir pembelajaran dengan pendekatan saintifik berbantuan handout pada pokok bahasan segiempat dan segitiga.

c. Peserta didik diajak dan dibimbing untuk bekerja sama dalam kelompok serta aktif dalam kegiatan diskusi kelompok maupun diskusi kelas sehingga terjadi interaktivitas saat pembelajaran berlangsung dan peserta didik diarahkan untuk mengambil andil tugas dalam kegiatan kelompok dengan membagi tanggung jawab anggota kelompok masing-masing.

d. Guru memotivasi peserta didik untuk berani menyampaikan pendapat, memberikan tanggapan dan aktif bertanya jika ada yang kurang dimengerti saat diskusi kelompok, presentasi penyajian materi, ataupun saat mengerjakan latihan soal, serta berani berpendapat untuk memberikan kesimpulan pembelajaran.
Skor rata-rata observasi aktivitas peserta didik pada siklus I adalah 14 dengan kategori kurang aktif, pada siklus II yaitu 20,375 dengan kategori cukup aktif, dan pada siklus III yaitu 26,5 dengan kategori aktif.

\section{Saran}

Berdasarkan penelitian yang telah dilaksanakan peneliti, terdapat beberapa saran yang dapat diberikan sebagai berikut :

1. Guru mata pelajaran matematika sebaiknya menerapkan model active learning start with a question dengan berbantuan handout pada pokok bahasan yang cocok dan sesuai dengan kurikulum sekolah sebagai variasi model pembelajaran sehingga peserta didik tidak merasa bosan dan meningkatkan keaktifan peserta didik dalam proses pembelajaran.

2. Guru hendaknya memperhatikan kedisiplinan waktu kepada peserta didik saat pelaksanaan kegiatan tiap tahapan model active learning start with a question agar pembelajaran menjadi lebih efektif.

3. Guru dapat menggunakan pendekatan persuasif (menegur, memotivasi, dan mengakrabkan diri) kepada peserta didik agar pembelajaran berjalan dengan baik.

4. Penelitian selanjutnya, hendaknya peneliti memasukkan dua aktivitas belajar yang belum dimasukkan pada penelitian ini, yaitu drawing activities dan emotional activities.

\section{DAFTAR PUSTAKA}

Arikunto,S.Suhardjono\&Supardi.2014.Penelitia n Tindakan Kelas.Jakarta: PT Bumi Aksara Hosnan,M.2014.Pendekatan Saintifik dan kontekstual Dalam Pembelajaran Abad 21.Bogor: Ghalia Indonesia

Kunandar.2013.Langkah Mudah Penelitian Tindakan Kelas. Jakarta: PT Raja Grasindo Persada

Muhammadi.2011.Mozaik Pembelajaran Inovatif.Padang: Sukabina Press

Sardiman.2011.Interaksi dan Motivasi Belajar Mengajar.Jakarta: PT Raja Grasindo Persada 
Sudjana, Nana.2011.Penilaian Hasil Proses Belajar Mengajar.Bandung: PT Remaja Rosdakarya

Silberman,Melvin.2016.Active Learning: 101 Cara Belajar Siswa Aktif..Bandung: Nuansa

Sudijono, Anas. 2008. Pengantar Evaluasi Pendidikan. Jakarta: Raja Grafindo Persada.

Susatyo,E.B., S.M. Rahayu \& R.Yuliawati.2009. Penggunaan Model Learning Start With A Question dan Self Regulatif Learning Pada Pembelajara Kimia.Universitas Negeri Semarang: Jurnal Inovasi Pendidikan Kimia, 3 (1): 406-412

Supriyadi.2015.Strategi Belajar

Mengajar.Yogyakarta: Cakrawala Ilmu
Suseno,H.2016.Penerapan Model Inquiry Learning dengan Pendekatan Saintifik Untuk Meningkatkan Keterampilan Abstrak dan Prestasi Belajar Fisika Siswa SMA.Jurnal Edukasi dan Sains.Vol.4, No. 1

Wartahati,K., Sofia Edriati \& Siskha Handayani.2015.Penerapan Strategi Aktif Tipe Learning Start With A Question Dalam Pembelajaran Matematika Siswa Kelas IX SMP Muhammadiyah 6 Padang.STKIP PGRI Sumatera Barat.

Zaini, Munthe dan Aryani.2017.Strategi Pembelajaran Aktif.Yogyakarta:CTSD (Center for Teaching Staff Development) 